\title{
HUBUNGAN OBESITAS, UMUR DAN JENIS KELAMIN TERHADAP KADAR KOLESTEROL DARAH
}

\author{
Lilis Sugiarti ${ }^{1 *}$, Latifah $^{2}$ \\ ${ }^{1}$ Jalan Baru Km 4 Cimanggu, Tanah Sareal, Bogor 16166 \\ Telp (0251) 8340217, 7535605, 7538760 Fax. (0251)7535605, \\ ${ }^{2}$ Rumah Sakit Bina Husada \\ Jl. Mayor Oking Jayaatmaja Km. 1 No. 101 Cibinong Bogor \\ Telp (0251) 8753422 \\ *e-mail : lilis_suwarno@yahoo.co.id
}

\author{
ABSTRACT \\ Relationship between Obesitiy, Age, Sex, and Blood Cholesterol Content \\ By. Lilis Sugiarti and Latifah
}

\begin{abstract}
Obesitiy is a health condition in which excess of body fat that accumulated in the fatty tissue, and it may have an adverse effect on health that leading to reduced the life expectancy and/or increased health problems. The research purpose was to see the correlation between obesity and age towards blood cholesterol level. 150 respondent samples were pasients who coming to Laboratorium of an hospital who examined their cholesterol level. The method of the research was descriptive method with focusing to the sectional cross, and the data were analysed with the Pearsion correlation method. To see the effect of obesity and age towards blood cholesterol increase used the double regression. The experimental result showed that there was correlation very significantly between age and blood cholesterol, while between obesity and blood cholesterol content was significant only .
\end{abstract}

Keywords : Obsity, cholesterol, age, sex

\section{ABSTRAK}

Obesitas adalah keadaan kesehatan dan stuktur gizi dengan akumulasi lemah tubuh berlebihan disertai dengan resiko kelainan patologis multi organ, atau secara sederhana obesitas didefinisikan sebagai keadaan penumpukan lemak yang berlebihan di dalam jaringan lemak sehingga mengganggu kesehatan..Tujuan dari penelitian ini adalah untuk mengetahui hubungan (korelasi) antara obesitas, umur dan jenis kelamin dengan kadar kolesterol darah, serta mengetahui pengaruh obesitas, umur dan jenis kelamin terhadap kenaikan kadar kolesterol darah. Populasi yang diambil sebagai sampel yaitu pasien yang berkunjung di Laboratorium Klinik RS Bina Husada yang memeriksakan kadar kolesterol darahnya, sebanyak 150 orang. Jenis penelitian yang digunakan adalah metode deskriptif dengan pendekatan cross sectional ,yang selanjutnya data diolah dengan metode Pearsion correlation. Sedang untuk melihat pengaruh obesitas dan umur terhadap kenaikan kadar kolesterol darah dengan metode Regresi berganda. Berdasarkan hasil penelitian maka dapat ditarik kesimpulan sebagai berikut: Terdapat hubungan (korelasi) yang sangat nyata antara umur dengan kadar kolesterol, sedangkan hubungan (korelasi) antara obesitas (IMT) dengan kadar kolesterol nyata.

Kata kunci : Obesitas, kolesterol, umur, jenis kelamin

\section{PENDAHULUAN}

Peningkatan kesejahteraan masyarakat terutama diperkotaan membuat kesadaran akan makanan yang bergizi semakin baik. Tetapi kadang hal tersebut membuat konsumsi makan yang berlebihan, serta kemajuan tehnologi yang mebuat aktifitas fisik berkurang sehingga memicu peningkatan kelebihan berat badan yang populer dengan nama obesitas.

Obesitas adalah keadaan kesehatan dan stuktur gizi dengan akumulasi lemak tubuh berlebihan disertai dengan resiko kelainan patologis multi organ, atau secara sederhana obesitas didefinisikan sebagai keadaan penumpukan lemak yang berlebihan di dalam jaringan lemak sehingga mengganggu kesehatan. Keadaan ini juga disebabkan oleh ketidakseimbangan antara energi yang masuk dan yang digunakan tubuh sehingga berat badan meningkat (Sonnenberg, 2007)

World Health Organization (WHO) menyatakan bahwa obesitas merupakan salah satu kondisi (dari 10 kondisi) yang beresiko di seluruh dunia dan salah satu dari 5 kondisi yang berisiko di negara-negara berkembang. Seluruh dunia lebih dari 1 milyar orang dewasa mempunyai berat badan berlebih. Kemungkinan di waktu mendatang epidemi obesitas akan melanda negara-negara di 
benua Asia. Bentuk tubuh orang Asia yang rata-rata lebih kecil dari penduduk negara Barat, tetapi mempunyai komposisi lemak visceral yang lebih banyak, merupakan salah satu faktor penting meningkatnya penyakit kardiovascular di Asia. Sedangkan di Indonesia diperkirakan lebih dari 17,5\% overweight dan 4,7\% obesitas (Budiono, 2007).

Penyakit kardiovaskular ini antara lain disebabkan oleh aterosklerosis. Aterosklerosis merupakan perubahan/pengerasan dinding pembuluh nadi, antara lain disebabkan oleh adanya penumpukan kolesterol. Proses aterosklerosis dapat mengenai pembuluh darah nadi berbagai organ salah satunya arteri koroner yang memperdarahi otot jantung sehingga menyebabkan penyakit kardiovaskular, salah satunya penyakit jantung koroner. Bertambahnya populasi obesitas dengan sendirinya akan mengakibatkan angka resiko penyakit jantung koroner. Laporan WHO tahun 2003 menunjukkan bahwa kematian akibat penyakit jantung mencapai $29,2 \%$ dari seluruh angka kematian dunia atau dari 16,7 juta jiwa 7,2 juta jiwa meninggal karena penyakit jantung koroner, setiap tahun dan sisanya meninggal karena hipertensi dan penyakit jantung lainnya (Marzuki S, 2007)

Menurut survei kesehatan nasional tahun 2001 diperoleh gambaran penyebab kematian akibat penyakit jantung di Indonesia yaitu $16 \%$ pada tahun 1992, 18,9\% pada tahun 1995 dan 26,4\% tahun 2001 (http://www.obesitas.web.id/ indonesia). Melihat data tersebut terlihat bahwa prosentasi kematian akibat penyakit jantung koroner dari tahun ke tahun meningkat cukup pesat. Akibat hal tersebut di atas, dipandang perlu melakukan penelitian guna mengetahui hubungan obesitas dengan kenaikan kadar kolesterol darah.Tujuan dari penelitian ini adalah untuk mengetahui hubungan (korelasi) antara obesitas dan umur dengan kenaikan kadar kolesterol darah dan mengetahui pengaruh obesitas dan umur terhadap kenaikan kadar kolesterol darah. Populasi yang diambil sebagai sampel yaitu pasien yang berkunjung di Laboratorium Klinik RS Bina Husada yang memeriksakan kadar kolesterol darahnya, sebanyak 150 orang.

\section{METODE PENELITIAN}

\section{A. Alat}

Alat yang digunakan untuk kegiatan penelitian ini adalah spuit, sentrifuge, kapas beralkohol, tabung reaksi, spektrofotometer
COBAS MIRA sn 120, timbangan, meteran dan komputer.

\section{B. Bahan}

Sedangkan bahan yang digunakan adalah bahan serum kontrol yang telah diketahui kadar kolesterol darahnya dari produk BIOCON dan darah yang diambil dari pasien yang datang ke laboratorium RS Bina Husada untuk memeriksa keadaan kolesterol darahnya sebanyak 150 orang.

\section{Pengumpulan Data}

Tahap pertama yaitu pengumpulan data diperoleh dari pasien yang datang ke laboratorium untuk memeriksakan kadar kolesterol darah, kemudian di catat nama, jenis kelamin, umur, tinggi badan dan berat badan pasien.Selanjutnya mengukur Indeks Masa Tubuh (IMT) untuk menentukan apakah pasien masuk kedalam klasifikasi berat badan berlebih atau tidak, dilakukan penghitungan IMT dengan rumus sebagai berikut :

IMT $: \frac{\mathrm{BB}(\mathrm{kg})}{\mathrm{TB}^{2}\left(\mathrm{~m}^{2}\right)}$

Dimana :

$\begin{array}{ll}\text { IMT } & =\text { Indeks Masa Tubuh } \\ \mathrm{TB} & =\text { Tinggi Badan }(\mathrm{m}) \\ \mathrm{BB} & =\text { Berat Badan }(\mathrm{kg})\end{array}$

\section{Pengukuran Kadar Kolesterol}

Pertama-tama lengan pasien dipasang tali pengikat untuk membendung aliran darah balik sehingga pembuluh darah vena membesar. Kemudian pembuluh venanya dicari dengan cara diraba. Setelah pembuluh darah vena teraba, kulit dimana pembuluh darah teraba diusap dengan kapas beralkohol. Selanjutnya pasien diambil sampel darahnya di vena lengan sebanyak $3 \mathrm{~mL}$ dengan menggunakan spuit ukuran $3 \mathrm{~mL}$ dengan jarum nidle ukuran 22 G. Sampel darah didiamkan selama 15 menit, diputar menggunakan sentrifuge selama 10 menit dengan kecepatan 3.000 rpm untuk diambil serumnya. Serum dipisahkan dari sel darah merah, diambil sebanyak $100 \mu \mathrm{L}$, dimasukkan ke dalam tabung sampel berukuran $300 \mu \mathrm{L}$. Serum diperiksa kadar kolesterol darahnya dengan alat spektrofotometer dengan langkah langkah sebagai berikut : 
Pertama-tama alat spektrofotometer dinyalakan, kemudian reagensia kolesterol darah dan serum kontrol dikeluarkan dari lemari es, didiamkan 15 menit supaya mencapai suhu ruang. Setelah 15 menit kode dan passwod pemeriksa dimasukkan ke dalam progam spektrofotometer dengan cara menekan tombol progam, 1, nama pemeriksa, passwod pemeriksa, kemudian enter. Reagensia kolesterol ditempatkan pada rak reagensia sedangkan serum kontrol ditempatkan ke dalam rak sampel, kemudian berturut-turut ditekan tombol rutin, 1, enter, D (kolesterol), enter dan star. Secara otomatis alat akan melakukan pemeriksaan kadar kolesterol darah kontrol dalam waktu 6 menit. Apabila hasil kadar kolesterol darahnya sesuai dengan nilai kontrol, selanjutnya dilakukan pemeriksaan kadar kolesterol darah sampel. Sebanyak $0,1 \mathrm{~mL}$ serum sampel dipipet dan dimasukkan ke dalam tabung sampel berukuran kecil, kemudian diletakkan ke dalam rak sampel. Langkah selanjutnya berturut-turut ditekan tombol rutin, 2, enter, D, 1 enter, dan star. Setelah 6 menit kadar kolesterol darah sudah terbaca di alat spektrofotometer.

\section{E. Analisis Data}

Untuk mengetahui hubungan IMT, umur, dan jenis kelamin terhadap kadar kolesterol darah, maka data yang dihasilkan diolah menggunakan metode statistik Pearson Corelation, dan bila hasilnya ada hubungan antara obesitas dan umur tehadap kenaikan kadar kolesterol darah, maka analisis dilanjutkan dengan Regresi Berganda untuk melihat seberapa besar pengaruh IMT dan umur terhadap kenaikan kadar kolesterol darah.

\section{HASIL DAN PEMBAHASAN}

\section{A. Karakteristik Pasien}

Pasien yang memeriksakan kolesterol darahnya di Rumah Sakit Bina Husada berjumlah 150 orang, yang didominasi oleh pasien wanita sebanyak 94 orang $(62,7 \%)$ dan sisanya 56 orang $(37,3 \%)$ laki-laki. Pasien berusia antara 30 sampai 62 tahun. Data disajikan pada tabel 2 dan gambar 5.

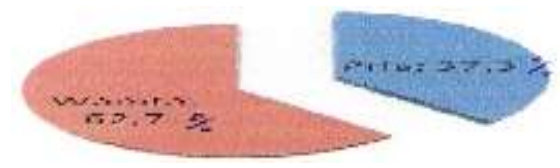

Gambar 5. Prosentase Jenis Kelamin dan Umur Pasien yang Memeriksakan Kadar Kolesterol Darah

\section{B. Indeks Masa Tubuh (IMT) dan Kadar Kolesterol Darah}

IMT merupakan salah satu cara pengukuran status gizi seseorang karena cara ini relatif sederhana dan mudah dilakukan. Berdasarkan hasil pengukuran berat dan tinggi badan pasien diperoleh nilai IMT. IMT merupakan indikator untuk menentukan pasien tersebut dalam kategori Normal (N), B.B.L. dan Obesitas (O), sedangkan untuk memperoleh nilai kadar kolesterol darah pasien diukur dengan menggunakan alat spektrofotometer.

1. Penggolongan pasien berdasarkan umur, klasifikasi IMT dan jenis kelamin.

Sebanyak 150 orang yang diperiksa yang termasuk dalam klasifikasi IMT Normal sebanyak 51 orang (34\%), B.B.L. sebanyak 32 orang (21\%), dan Obesitas sebanyak 67 orang $(45 \%)$. Sedangkan dari 51 orang klasifikasi IMT Normal, 28 orang $(55 \%)$ wanita dan 23 orang (45\%) laki-laki, dari 32 orang klasifikasi IMT B.B.L., 21 orang (66\%) wanita dan 11 orang (34\%) laki-laki, dan dari 67 orang klasifikasi IMT Obesitas, 45 orang $(67 \%)$ wanita dan 22 orang (33\%) laki-laki (tabel 3 dan gambar 6).

Melihat data tabel 3. terlihat bahwa pasien dengan klasifikasi IMT Obesitas cukup tinggi (45\%) dibandingkan penggolongan klasifikasi IMT yang lainnya yaitu IMT Normal dan B.B.L. Hal ini mengindikasikan bahwa prosentase masyarakat dengan klasifikasi IMT Obesitas meningkat.Epidemi obesitas dijelaskan dengan meningkatnya konsumsi energi dan atau penurunan pengeluaran energi, perubahan faktor-faktor lingkungan, mutasi genetik baru, serta juga peningkatan kelainan hormonal terkait obesitas. Epidemi obesitas ini melintasi batas budaya. Seluruh dunia menjadi lebih besar prosentasi obesitas dengan perbaikan ekonomi, peningkatan akses atau keinginan terhadap makanan kalori tinggi, gula tinggi, dan kemajuan teknologi ikut mengurangi keaktifan fisik (Marzuki Suryaatmaja, 2007).

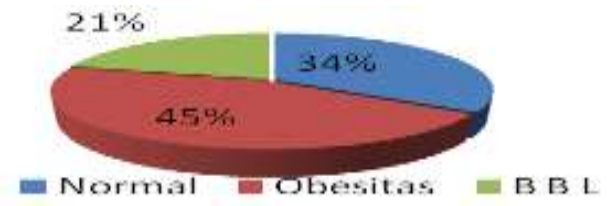

Gambar 6. Prosentase Total Pasien dalam Klasifikasi IMT. 
Sedangkan berdasarkan penggolongan umur dan jenis kelamin, pasien dengan umur 30-39 tahun, yang termasuk klasifikasi IMT Normal sebanyak $42 \%, 53 \%$ wanita dan $47 \%$ laki-laki, klasifikasi IMT B. B. L. $22 \%, 74 \%$ wanita dan 26\% laki-laki, dan klasifikasi IMT Obesitas $36 \%$, $77 \%$ wanita dan $33 \%$ laki-laki (lihat gambar $7 \mathrm{~A}$ ). Usia 40-49 tahun yang termasuk pada klasifikasi IMT Normal sebanyak $19 \%$ terdiri dari $33 \%$ wanita dan $67 \%$ laki-laki, klasifikasi IMT B. B. L. 28\%, 54\% wanita dan 46\% laki-laki, klasifikasi IMT Obesitas 53\% , 60\% wanita dan 40\% laki-laki (lihat gambar 7 B). Usia 50-59 tahun yang termasuk klasifikasi IMT Normal 33\%, 100\% wanita, klasifikasi IMT B. B. L. 0\%, klasifikasi IMT Obesitas 67\%, 60\% wanita dan 40\% laki-laki. Sedangkan usia $60-69$ tahun mempunyai klasifikasi yang sama dengan umur 50-59 tahun yaitu yang termasuk klasifikasi IMT Normal 33\%, dari $100 \%$ wanita, klasifikasi IMT B.B.L. 0\%, klasifikasi IMT Obesitas $67 \%$ terdiri dari $50 \%$ wanita dan 50\% laki-laki (lihat gambar 8).

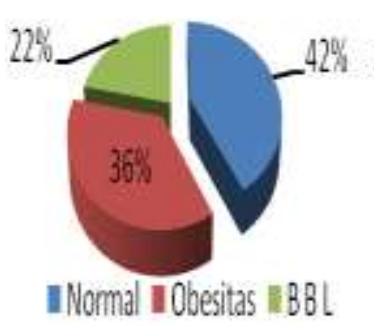

A

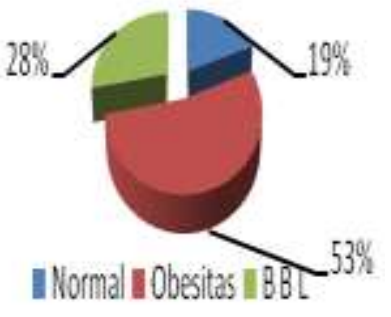

B
Gambar 7. Prosentase Pasien dalam Klasifikasi IMT pada umur 30-39 Tahun (A) dan umur 40-49 Tahun (B).

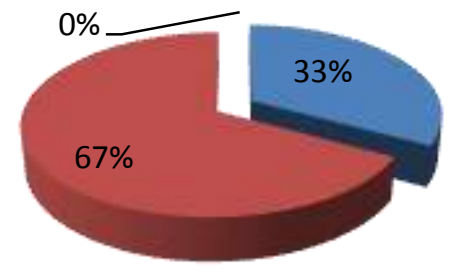

normal $\quad$ Obesitas $\quad$ B B L

Gambar 8. Prosentase Pasien dalam Klasifikasi IMT Umur 50-59 tahun/60-69 Tahun.
2. Penggolongan pasien berdasarkan kadar kolesterol darah.

Pasien yang memiliki kadar kolesterol kurang dari $200(<200)$, berarti termasuk golongan normal, sedangkan yang memiliki kadar kolesterol melebihi atau sama dengan $(\geq 200)$ termasuk golongan hiperkolesterolemia

Berdasarkan kategori normal atau tidaknya kadar kolesterol pasien, didapatkan data bahwa dari 150 orang pasien yang diperiksa kadar kolesterol darahnya $49 \%$ hiperkolesterolemia dan $51 \%$ normal. Bila dilihat dari penggolongan umur pasien maka yang terkena hiperkolesterolemia adalah pada usia 30 - 39 tahun sebanyak 37 orang, diikuti kelompok usia 40 - 49 tahun sebanyak 23 orang, diikuti kemudian oleh kelompok umur 50 59 tahun sebanyak 11 orang dan terakhir pada kelompok umur 60 - 69 tahun sebanyak 3 orang. (lihat tabel 4 dan gambar 9). Sebenarnya pada usia 30-39 yang merupakan usia produktif dan seharusnya banyak melakukan aktifitas fisik, tetapi karena sekarang ini kemajuan teknologi semakin meningkat pesat, sehingga aktifitas fisik berkurang, serta pola makan yang tidak sehat, misalnya makan makanan yang tinggi kadar lemak dan kalorinya, sedangkan energi yang dipergunakan sedikit sehingga menyebabkan tidak seimbangnya makanan yang masuk dan energi yang dikeluarkan, yang menyebabkan kelebihan kalori serta lemak disimpan dalam tubuh sehingga menyebabkan kenaikan kadar lemak dalam tubuh meningkat.

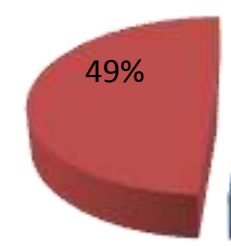

Normal

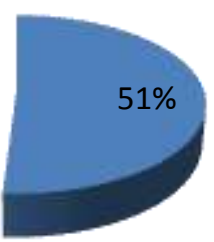

Hiperkolesterol
Gambar 9. Prosentase Pasien yang Normal dan Hiperko lesterolemia

Bila dilihat dari pasien yang termasuk klasifikasi IMT Obesitas sebanyak 67 orang (45\%), sebanyak 37 orang (56\%) mempunyai kadar kolesterol darah meningkat (hiperkolesterolemia) dan 30 orang $(44 \%)$ orang mempunyai kadar kolesterol darah normal (Gambar 10). Hal ini cukup menggambarkan bahwa obesitas berpengaruh 
terhadap kadar kolesterol darah yang merupakan salah satu faktor PJK, sehingga upaya mengurangi obesitas dengan cara pengaturan makan, olah raga, dan gaya hidup sehat secara tidak langsung mengurangi resiko terkena PJK. Data ini lebih tinggi dibandingkan data yang dilaporkan oleh Waspaj dkk pada tahun 1993 di Jakarta dengan populasi pasien sebanyak 34.648 yaitu prevalensi obesitas yang hanya sebesar $17,8 \%$, dengan $9,3 \%$ nya adalah hiperkolesterolemia.

Bila dilihat dari kelompok jenis kelamin, orang yang obesitas yang mempunyai kadar kolesterol tinggi (hiperkolesterolemia) sebanyak 36 orang $(69 \%)$, ternyata wanita lebih banyak yang terkena hiperkolesterolemia yaitu sebanyak 69\% sedangkan laki-laki sebanyak 31\%.

Dari 74 pasien yang hiperkolesterolemia $54,7 \%$ merupakan pasien dengan klasifikasi IMT Obesitas, 24\% dengan klasifikasi IMT B.B.L. dan sisanya 21,3\% dengan klasifikasi IMT Normal (lihat tabel 6 gambar 11), hal ini cukup menggambarkan bahwa kenaikan kadar kolesterol darah dipengaruhi oleh obesitas. Sehinga dirasa perlu untuk memberikan penyuluhan kepada masyarakat bahwa obesitas akan menimbulkan berbagai macam resiko. Karena selama ini masih ada yang beranggapan bahwa kegemukan adalah tanda kemakmuran dan kesuksesan.

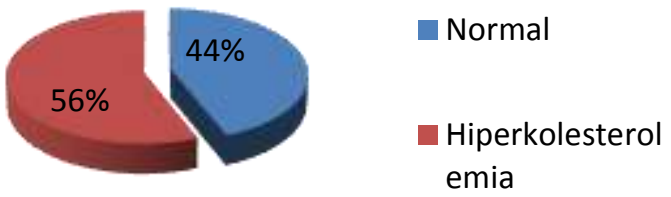

$\begin{array}{rlr}\text { Gambar 10. } & \text { Prosentasi Pasien dengan Kasifikasi } \\ & \text { Obesitas Antara yang } & \text { Kadar } \\ & \text { Kolesterol normal } & \text { dan } \\ \text { hiperkolesterolemia } & \end{array}$

Bila dilihat dari kelompok jenis kelamin orang yang obesitas yang mempunyai kadar kolesterol tinggi (hiperkolesterolemia) sebanyak 36 orang $(69 \%)$, ternyata wanita lebih banyak yang terkena hiperkolesterolemia yaitu sebanyak $69 \%$ sedangkan laki-laki sebanyak $31 \%$. Hal ini bisa dimengerti karena kebanyakan perempuan mempunyai aktifitas yang kurang menguras energi dibandingkan laki-laki, disamping itu juga ditunjang dari budaya setempat misalnya budaya timur yang masih membedakan jenis pekerjaan antara perempuan dan laki-laki.

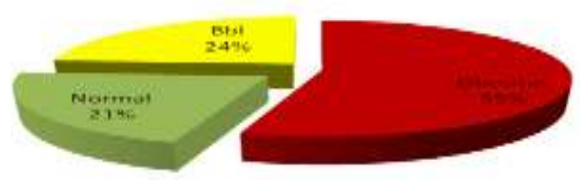

Gambar 11. Prosentase Pasien Hiperkolesterolemia dengan Berat Badan Berlebih (BBL), Obesitas, dan normal.

Dari keseluruhan data diatas terlihat bahwa orang terkena hiperkolesterolemia $49 \%$ dari pasien yang diperiksa (150 orang), ini merupakan angka yang cukup tinggi, sehingga sangat perlu diantisipasi dengan memberikan penyuluhan yang lebih intensif tentang pola hidup sehat disertai penjelasan tentang penyakit-penyakit yang akan menyertainya seperti aterosklerosis serta penyaki kardiovaskular.

3. Penggolongan kadar kolesterol darah normal dan hiperkolesterol berdasar jenis kelamin.

Berdasarkan Tabel 7 di bawah ini menunjukkan bahwa kecenderungan pasien lakilaki- atau wanita yang memiliki kadar kolesterol normal $(<200)$ dan yang memiliki kadar kolestereol di atas atau sama dengan $200(\geq 200)$ adalah pada usia 30-39 tahun diikuti pada usia 40-49 tahun, dan selanjutnya diikuti berturut turut pada kelompok usia 50-59 tahun dan 60-69 tahun. Hal tersebut dapat menggambarkan bahwa ternyata pada kelompok umur yang lebih muda yang seharusnya mempunyai aktifitas fisik tinggi justru mempunyai kadar kolesterol yang lebih tinggi, karena saat ini kemajuan tehnologi yang memungkinkan aktifitas fisik berkurang dan penigkatan akses atau keingginan terhadap makanan yang berkalori dan berlemak yang merupakan faktor -faktor yang turut memicu peningkatan kadar kolesterol darah. Sehingga perlu dilakukan penyuluhan kepada masyarakat tentang pola hidup sehat disertai penjelasan tentang penyakit yang akan menyertainya.

Untuk melihat potensi apakah jenis kelamin laki-laki atau wanita yang termasuk golongan normal atau hiperkolesterolemia dengan jumlah responden laki-laki sama dengan jumlah responden wanita, ternyata wanita lebih berpotensi untuk terkena hiperkolesrolemia dibandingkan laki-laki seperti disajikan pada Tabel 7. 
Tabel 7. Golongan Kolesterol Berdasar kan Usia dan Jenis Kelamin

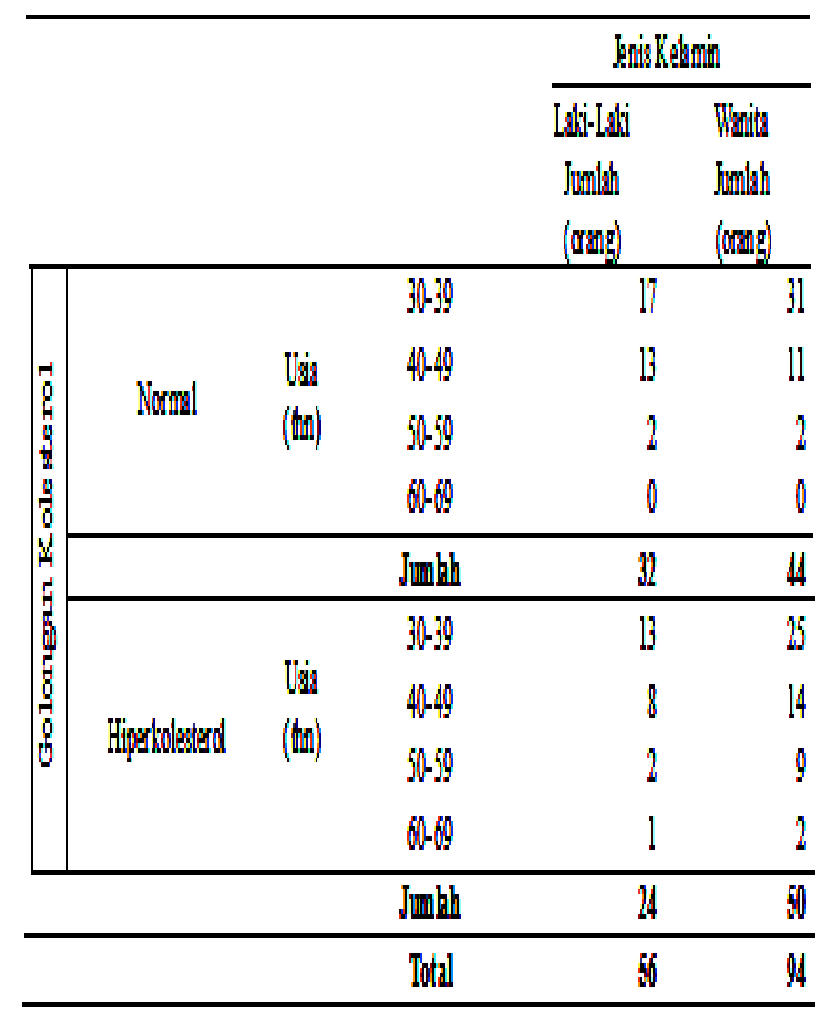

Tabel 8. Potensi jenis kelamin terkena kolesterolemia

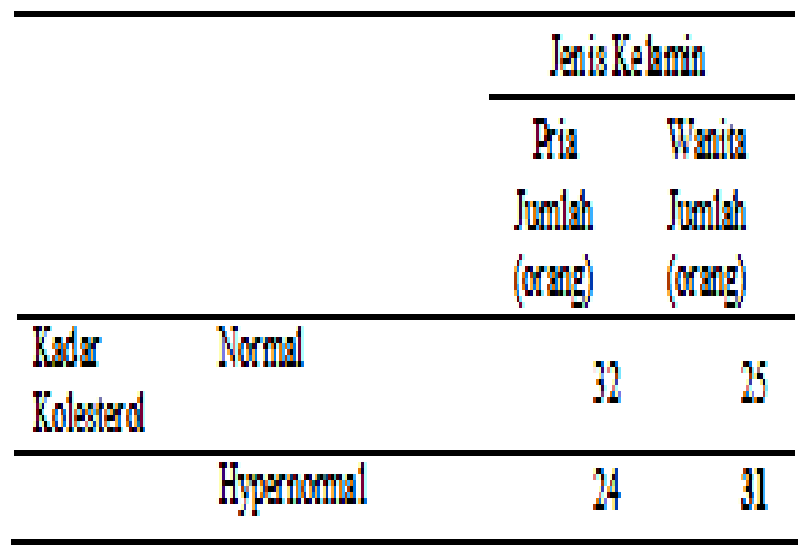

Dari keseluruhan data di atas terlihat jelas peningkatan prevalensi obesitas, yang mengindikasikan epidemi obesitas yang secara tidak langsung memicu peningkatan kadar kolesterol darah yang merupakan salah satu pemicu penyakit kardiovaskular sudah masuk ke negaranegara berkembang seperti Indonesia yang merupakan salah satu akibat dari perbaikan ekonomi, peningkatan akses atau keinginan terhadap makanan kalori tinggi, gula tinggi, dan kemajuan teknologi ikut mengurangi keaktifan fisik.

Dari data tersebut diatas juga terlihat bahwa daerah Cibinong (wilayah dimana dilakukan penelitian ini) yang merupakan daerah pinggiran kota Jakarta, prosentasi obesitas dan kadar kolesterolemia cukup tinggi.

\section{Korelasi antar Variabel}

Berdasarkan Tabel 9 terlihat bahwa variabel umur berkorelasi sangat nyata dan positif dengan variabel indek masa tubuh, dan variabel kadar kolesterol darah, yang artinya semakin bertambah umur maka semakin bertambah tinggi pula nilai indeks masa tubuh dan semakin bertambah pula kadar kolesterol darahnya. Sedangkan variabel indeks masa tubuh berkorelasi nyata dan positif dengan variabel kadar kolesterol darah, yang berarti bahwa semakin bertambah nilai indeks masa tubuh maka semakin meningkat kadar kolesterol darahnya. Sedangkan variabel jenis kelamin tidak menunjukkan korelasi dengan variabel kadar kolesterol maupun dengan variabel indek masa tubuh.

\section{Regresi Berganda}

Regresi berganda terdiri dari satu variabel dependen (Y) dalam hal ini adalah kadar kolesterol darah, dan dua variable independen yaitu X1 adalah umur dan X2 adalah IMT.

Berdasar hasil analisis $\mathrm{R}$ square (qhisquare) didapatkan nilai $\mathrm{R}^{2}$ adalah 0,168 , ini berarti $16,8 \%$ dari variasi kadar kolesterol darah manusia bisa dijelaskan oleh variabel umur dan indeks masa tubuh. Sedangkan sisanya (100\%$16,8 \%=83,2 \%$ ) disebabkan oleh faktor-faktor lain.

Seperti diketahui selain faktor umur dan IMT, ada faktor lain yang berpengaruh terhadap kadar kolesterol darah manusia misalnya kebiasaan merokok, herediter, stress, hormon seks, alkohol dan lain sebagainya.

Dari uji dua beda nyata, didapat bahwa, umur dan indeks masa tubuh yang dipakai secara bersama-sama berpengaruh terhadap kadar kolesterol darah. 
Tabel 9. Korelasi antar Variabel

\begin{tabular}{|c|c|c|c|c|c|}
\hline & & Umur & IMT & $\begin{array}{c}\text { Kadar } \\
\text { Kolesterol }\end{array}$ & Jenis Kelamin \\
\hline \multirow[t]{3}{*}{ Umur } & $\begin{array}{l}\text { Pearson } \\
\text { Correlation }\end{array}$ & 1 &, $215(* *)$ &, $398(* *)$ & ,034 \\
\hline & Sig. (2-tailed) & & ,008 &, 000 & ,682 \\
\hline & $\mathrm{N}$ & & 150 & 150 & 150 \\
\hline \multirow[t]{3}{*}{ IMT } & $\begin{array}{l}\text { Pearson } \\
\text { Correlation }\end{array}$ &, $215(* *)$ & 1 &, $179(*)$ & ,098 \\
\hline & Sig. (2-tailed) & ,008 & & 028 & ,235 \\
\hline & $\mathrm{N}$ & 150 & & 150 & 150 \\
\hline \multirow[t]{3}{*}{ Kadar Kolesterol } & $\begin{array}{l}\text { Pearson } \\
\text { Correlation }\end{array}$ &, $398(* *)$ &, $179\left(^{*}\right)$ & 1 &, 121 \\
\hline & Sig. (2-tailed) &, 000 & ,028 & & ,139 \\
\hline & $\mathrm{N}$ & 150 & 150 & & 150 \\
\hline Jenis Kelamin & $\begin{array}{l}\text { Pearson } \\
\text { Correlation } \\
\text { Sig. (2-tailed) } \\
N\end{array}$ & $\begin{array}{l}, 034 \\
, 682 \\
150\end{array}$ & $\begin{array}{l}, 098 \\
, 235 \\
150\end{array}$ & $\begin{array}{l}, 121 \\
, 139 \\
150\end{array}$ & 1 \\
\hline
\end{tabular}

** Correlation is significant at the 0.01 level (2-tailed).

* Correlation is significant at the 0.05 level (2-tailed)

Berdasarkan uji beda dua nilai rata-rata dari sampel yang berhubungan, ternyata umur berpengaruh secara Nyata terhadap kadar kolesterol darah, sedangkan IMTsa tubuh tidak berpengaruh nyata terhadap kadar kolesterol darah.

Persamaan regresi bergandanya adalah :

$\mathrm{Y}=99,200+1,173 \mathrm{X}_{1}+1,922 \mathrm{X}_{2}$

Dimana :

$\mathrm{Y}=$ Kadar kolesterol darah

$\mathrm{X}_{1}=$ umur

$\mathrm{X}_{2}=$ Indeks Masa Tubuh.

Maksud dari konstanta sebesar 99,200 adalah jika tidak ada penambahan umur (tahun) dan indeks masa tubuh (tinggi dan berat badan), kadar kolesterol sebesar 99,200.

Sedangkan koefisien regresi $\mathrm{X}_{1}$ sebesar 1,173 menyatakan bahwa setiap penambahan satu tahun umur, kadar kolesterol darah adalah 1,173. Demikian untuk koefisen regresi $\mathrm{X}_{2}$ sebesar 1,992 menyatakan bahwa setiap penambahan $1 \mathrm{~kg} / \mathrm{m} 2$ akan memungkinkan kadar kolesterol darah meningkat sebesar 1,992.

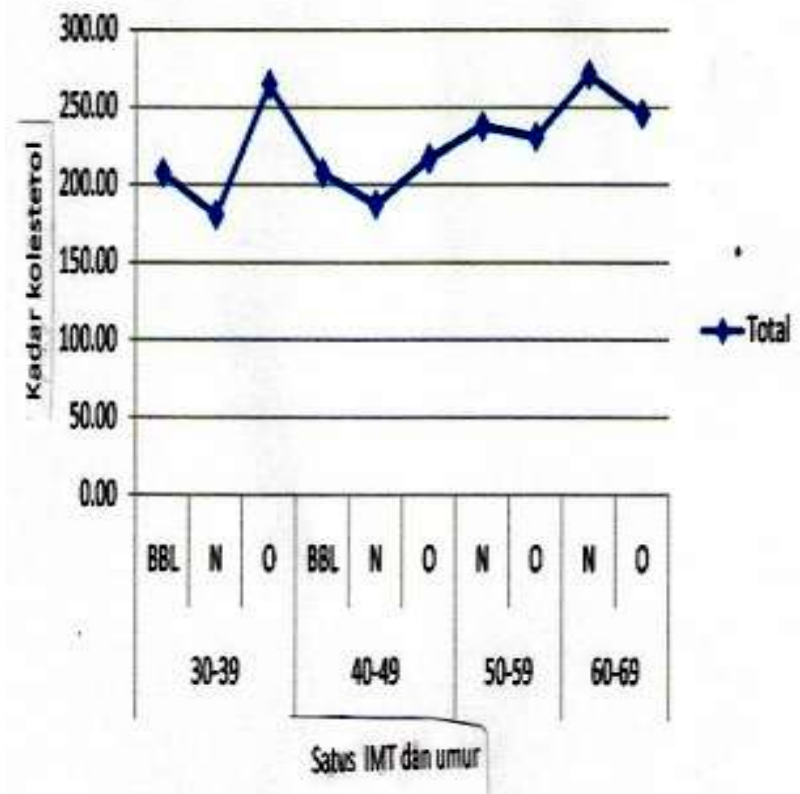

Gambar 12. Hubungan antara umur, golongan IMT dan kadar kolesterol 
Pada gambar 12 terlihat pada umur 30-39 tahun pasien yang mempunyai klasifikasi IMT O yang mempunyai kadar kolesterol darah yang paling tinggi, sedangkan kolesterol yang paling rendah terdapat pada pasien berumur 40-49 tahun dengan IMT normal.

\section{KESIMPULAN DAN SARAN}

\section{A. Kesimpulan}

Berdasarkan hasil penelitian maka dapat ditarik kesimpulan sebagai berikut :

1. Terdapat hubungan (korelasi) yang sangat nyata antara umur dengan kadar kolesterol, sedangkan hubungan (korelasi) antara obesitas (IMT) dengan kadar kolesterol nyata, sedangkan jenis kelamin tidak ada hubungan (korelasi) dengan obesitas maupun jenis kelamin. Koefisien diterminasi $\left(\mathrm{R}^{2}\right)$ sebesar $16,8 \%$ yang berarti variasi kadar kolesterol darah manusia bisa dijelaskan oleh variabel umur dan indeks masa tubuh. Sedangkan sisanya $(100 \%-16,8 \%=83,2 \%)$ dijelaskan oleh sebab-sebab lain.

2. Pengaruh umur $\left(\mathrm{X}_{1}\right)$ dan IMT $\left(\mathrm{X}_{2}\right)$ terhadap kadar kolesterol darah(Y) seperti pada persamaan berikut : $\mathrm{Y}=99,200+1,173 \mathrm{X}_{1}+$ $1,922 \mathrm{X}_{2}$, yang berarti setiap penambahan umur (per tahun) maka kadar kolesterol bertambah 1,173 satuan dan penambahan IMT satu satuan maka kadar kolesterol bertambah 1,922 satuan.

\section{B. Saran}

Perlu dilakukan penelitian lebih lanjut untuk mengetahui faktor-faktor lain yang berpengaruh secara nyata terhadap kenaikan kadar kolesterol darah manusia.

\section{DAFTAR PUSTAKA}

Anonin. 2008. Obesitas. http:// www. obesitas.web.id/indonesia. Diakses tanggal 23 Juli 2009.

Budiono, B. 2007. Sindroma metabolik dan Penyakit kardiovaskuler. Fakultas Kedokteran Universitas Hasanudin. Penerbit UNHAS Pers. Makasar.
Bosco WT, Jr. 2005. Obesity and The Metabolic Syndrome. Medscape

Cristie.W. 2003. Lipid Analisis : Isolasi, Pemisahan, Indentifikasi, dan Analisis Struktural . Lipids. Ayr, : ISBN 09531949-5-7. Skotlandia

D. W. Martin Jr, P. A. Mayes, V. W. Rodwell. 1983 Biokimia (Review of Biochemistry) Edisi 9. C. V. EGC Penerbit Buku Kedokteran. Jakarta

Gordon. D. J. ed al. 1989, High-Density Lipoprotein Kolesterol dan Penyakit Cardiovascular, Sirkulasi 79 (1) : 8-15. Pmid 2642759.

Marzuki Suryaatmaja. 2007. Sindrom Metabolik. Laboratorium American Bio- Clinic Vol 8, No. 2. Jakarta.

Marzuki Suryaatmaja. 2006. Aterosklerosis dan Penyakit Kardiovaskular. Laboratorium American Bio-Clinik. Jakarta.

Olson RE. 1998. Discovery Of Lipoproteins, Peranan Mereka dalam Lemak Transportasi dan Kepentingan Mereka sebagai Faktor Risiko. J. Nutr. 128 (2 Suppl) : 439S-443S. Pmid 9478044.

Smith L. 1991. Satu Hipotesa Kolesterol : Kolesterol sebagai Antioxidant. Biologi. Med. 11 (I) : 47-61. Doi : 10.106/08915849. Pmid 1937129.

Sonnenberg GE. 2007. Drug treatments for obesity : Where are we heading and how do we get there? BR J Diabetes Vasc Dis.; 7 (3) : 111-118.

Van der Steeg WA. 2008. "High-density lipoprotein kolesterol tinggi kepadatan lipoprotein particle ukuran dan apolipoprotein. $\mathrm{J}$

WHO/IOSO/IOTF. 2000. The Asian-Pasific Perspective : Redefining Obesity and Its Treatment. Health Communications Australia : Melboune. The Asian-Pasific Perspective : Redefining Obesity and Its. 